\title{
Down-regulation of heart HFABP and UCP2 gene expression in diet-induced (cafeteria) obese rats
}

\author{
A. Marti, J. Vaquerizo, M. A. Zulet, M. J. Moreno-Aliaga and J. A. Martínez \\ Dpto. de Fisiología y Nutrición, Universidad de Navarra, \\ 31008 Pamplona, Navarra, Spain.
}

(Received on April 9, 2002)

\begin{abstract}
A. MARTI, J. VAQUERIZO, M. A. ZULET, M. J. MORENO-ALIAGA and J. A. MARTÍNEZ. Down-regulation of heart HFABP and UCP2 gene expression in diet-induced (cafeteria) obese rats. J. Physiol. Biochem., 58 (2), 69-74, 2002

Long-term exposure to hypercaloric high fat diet induced marked tissue fatty acid accumulation and may influence cell function. Previous results in our laboratory showed that uncoupling proteins (UCPs) and fatty acid-binding protein (FABP) gene expression are changed in adipose tissue and skeletal muscle tissue in diet-induced (cafeteria) obese animals. The aim of this study was to examine heart FABP (HFABP) and UCP2 gene expressions in dietary obese rats. Rats fed on a high-fat diet for 65 days had significantly higher fat stores and body weight than control rats. Interestingly, we found that both HFABP and UCP2 mRNA levels were significantly reduced in cafeteria-obese rats when compared to control animals. Moreover, a statistically significant correlation was observed between the two gene expression levels. The down-regulation of heart HFABP and UCP2 parallels the lower lipid utilization which may account for an enhanced fat deposition. It is plausible that these two genes are regulated by the same family of transcription factors.
\end{abstract}

Key words: Cafeteria diet, UCP2, HFABP, Heart.

Long-term exposure to hypercaloric high fat diet induced an important tissue fatty acid accumulation and may influence cell function. Previously, our team has shown that uncoupling proteins (UCPs) and fatty acid-binding protein (FABP) were modified in adipose tissue and skeletal muscle of diet-induced obese animals $(3,7,10)$. In this work, our interest was to

Correspondence to A. Marti (Tel.: 34948425 600; Fax: 34948425 649; e-mail: amarti@unav.es). evaluate changes in heart gene expression in order to increase our understanding of the potential heart damage associated with obesity status $(1,17)$.

In cardiac muscle, fatty acids are the main source of energy and high fat feeding may change gene expression. The heart fatty acid-binding protein (HFABP) is a member of a family of binding proteins, mainly present in skeletal and cardiac muscle, with diverse roles in fatty acid metabolism, trafficking, and signaling (4). 
HFABP is essential for normal myocardial fatty acid oxidation while serves as a modulator of fatty acid uptake in skeletal muscle (13). HFABP mRNA levels are increased by testosterone administration and in response to fasting or exercise in heart, probably due to a higher fatty acids oxidation rate (15). The administration of lipopolysaccharide decreased the expression levels of HFABP in heart (11), and recent work suggests that $\mathrm{HFABP}$ protein levels are a good indicator of myocardial damage (12).

The uncoupling protein 2 (UCP2), expressed in cardiac and skeletal muscle among other tissues, may have a role in metabolic efficiency and/or fat accumulation $(8,16)$. In response to fasting, UCP2 mRNA levels are increased in skeletal but not in cardiac muscle in response to fasting (5), while UCP2 mRNA levels were decreased in skeletal muscle after high-fat feeding (3). We sought to investigate the expression levels of these two genes (HFABP and UCP2) in cardiac muscle of obese (cafeteria) rats.

\section{Materials and Methods}

Animals and treatment.- Twenty Wistar (six weeks old) male rats, obtained from Applied Pharmacobiology Center (CIFA-SPAIN) were selected for this study. The animals were housed in cages under controlled conditions of light $(12 / 12 \mathrm{~h}$. light/dark) and temperature (22 $\pm 2^{\circ} \mathrm{C}$ ). All experimental procedures were performed according to European and Institutional Guidelines for Animal Care and Use at the University of Navarra (Directiva 86/609/CEE, 18 December 1986).

Rats were assigned to two dietary groups for 65 days, with one group (Control, $\mathrm{n}=10$ ) fed standard laboratory pelle- ted diet, while the second group (Cafeteria diet, $\mathbf{n}=10$ ) was fed a fat-rich hypercaloric diet containing pate, chips, chocolate, bacon, biscuits and chow in a proportion of $4: 2: 2: 2: 2: 2$ as previously published $(3,7,10)$. All materials were weighed before feeding and presented in excess. The animals were weighed daily.

Cardiac muscle and fat pads tissue were dissected and immediately weighed after the animals were killed by decapitation. Samples of cardiac muscle were frozen at $-80^{\circ} \mathrm{C}$ for subsequent RNA extraction.

Biochemical measurements.- Serum glucose, glycerol, triglycerides and free fatty acids were analyzed using an Autoanalyzer (Cobas Roche Diagnostic, Basel, Switzerland) by routine procedures. Plas$\mathrm{ma}$ insulin was assayed by RIA using ${ }^{125}$ I-labeled insulin (Diagnostic Products Corporation, Los Angeles, CA, USA) with a human insulin standard.

Extraction of total RNA and semiquantification by reverse transcription-polymerase chain reaction $(R T-P C R)$.-Total RNA was isolated by the Ultraspec-II RNA Isolated System (Biotech) from 100 $\mathrm{mg}$ of cardiac muscle according to a previously reported procedure with some modifications (6). After 60 min treatment with RNase free DNase I at $37^{\circ} \mathrm{C}$ (Boehringer Mannheim), $1 \mu \mathrm{g}$ of RNA was used to synthesise first-strand cDNA. The RT reaction was carried out in a volume of 20 $\mu$ containing, $50 \mathrm{mM}$ Tris $-\mathrm{HCl}(\mathrm{pH} \mathrm{8.3)}$, $75 \mathrm{mM} \mathrm{KCl}, 3 \mathrm{mM} \mathrm{MgCl} 2,10 \mathrm{mM}$ dithiotreitol, $100 \mathrm{ng}$ of random hexamers (Boehringer Mannheim), $1 \mathrm{mM}$ each dNTP (Bioline), 20 units of RNase inhibitor (Promega), 200 units of M-MLV (Moloney Murine Leukemia Virus) and incubated at $37^{\circ} \mathrm{C}$ for $60 \mathrm{~min}$. The enzyme was inactivated by heating at $95^{\circ} \mathrm{C}$ for $5 \mathrm{~min}$. 
Four $\mu$ from the RT reaction were amplified in a $50 \mu$ l reaction mixture containing $40 \mathrm{ng}$ of each primer, $16 \mathrm{mM}(\mathrm{NH} 4)_{2} \mathrm{SO}_{4}$, $67 \mathrm{mM}$ Tris $\mathrm{HCl}$ ( $\mathrm{pH} 8.8$ ), $2 \mathrm{mM} \mathrm{MgCl}$, $0.1 \%$ Tween-20, $0.2 \mathrm{mM}$ each dNTP and 1 unit of BIOTAQ polymerase (Bioline). Primers for UCP2, H-FABP and b-actin were designed using the Oligo, 5.05 Primer Analysis Software (National Biosciences, USA) and are shown in Table I. To ensure the linearity of $P C R$ reactions and to validate the cDNA quantitation, adequate controls and standard curves were carried out. A linear increase in PCR product was observed when using RNA ranging between 50 and $400 \mathrm{ng}$, all subsequent $P C R$ reactions were performed using $200 \mathrm{ng}$ of RNA. A second set of PCR reactions were design to determine the appropriate number of cycles as previously reported. Semiquantitative PCR estimates the relative amount of target RNA to a known housekeeping gene $(\beta$-actin) and eliminates the sample to sample variability of the RT-step, as well as the PCR step. cDNAs were amplified using the following parameters concerning annealing and elongation conditions: $57^{\circ} \mathrm{C}$ for $30 \mathrm{~s}$ and $72^{\circ} \mathrm{C}$ for $60 \mathrm{~s}$ during 26 cycles for HFABP, $62^{\circ} \mathrm{C}$ for $30 \mathrm{~s}$ and 72 ${ }^{\circ} \mathrm{C}$ for $60 \mathrm{~s}$ during 25 cycles for UCP2 and, $55^{\circ} \mathrm{C}$ for $30 \mathrm{~s}$ and $72{ }^{\circ} \mathrm{C}$ for $60 \mathrm{~s}$ during 25 cycles for 28 cycles for b-actin.
For all primers, a first step of denaturation was applied $\left(95^{\circ} \mathrm{C}\right.$ for $30 \mathrm{~s}$ ) along with a final extension step for $7 \mathrm{~min}$ at $72{ }^{\circ} \mathrm{C}$. Amplifications were linear under these conditions and carried out in a GeneAmp, PCR System 2400 (Perkin Elmer, USA). The amplified products were visualized in a $1.5 \%$ agarose gel with ethidium bromide. PCR bands intensity were semi-quantified by scanning densitometric analysis using the Gel Doc 1000 UV fluorescent gel documentation system and Molecular Analyst software for quantification of images (Bio-Rad, USA). Levels of mRNA were expressed as the ratio of signal intensity for $\mathrm{H}-\mathrm{FABP}$ and $\mathrm{UCP} 2$ relative to that for $\beta$-actin.

Statistical analysis.- Values are given as the means \pm SEM. The non-parametric or parametric test were used when appropiate to verify the difference between groups, with a minimum significance level of $\mathrm{p}<0.05$.

\section{Results and Discussion}

Rats eating the cafeteria-diet for 65 days exhibited a significant increase in body weight gain $(145 \%)$ and fat content $(216 \%)$ at the end of the experimental trial when compared to control animals (Table

Table I. Characteristics of PCR for the assessment of gene expression levels.

\begin{tabular}{|c|c|c|c|c|c|}
\hline Gen & & Primmers sequence & Length & Position & Key \\
\hline \multirow{2}{*}{ HFABP } & Sense & 5'-CAGGAAGGTCAAGTCGGTC-3' & \multirow{2}{*}{229} & $257-275$ & \multirow{2}{*}{ M18034 } \\
\hline & Antisense & 5'-CGTGGTGCTGAGTTAGGG-3' & & $451-468$ & \\
\hline \multirow{2}{*}{ UCP2 } & Sense & 5'-TAAAGCAAGTTCTACACCAAGGG-3' & \multirow{2}{*}{360} & $308-329$ & \multirow{2}{*}{ AF03903 } \\
\hline & Antisense & 5'-CGAAGGCAGAAGTGAAAGTGG-3' & & $667-648$ & \\
\hline \multirow{2}{*}{$\beta$-actin } & Sense & 5'-TCTACAATGAGCTGCGTGTG-3' & \multirow{2}{*}{314} & $1599-1618$ & \multirow{2}{*}{ J00691 } \\
\hline & Antisense & 5'-GGTCAGGATCTTCATGAGGT-3' & & $2376-2357$ & \\
\hline
\end{tabular}


Table II. Body weight gain, organ weight and plasma biochemical markers in obese (cafeteria diet) and control rats. $n=10^{\star \star \star \star} p<0.00 \dagger$ vs control group.

\begin{tabular}{lcc}
\hline & Control & Obese \\
\hline Weight gain $(\mathrm{g})$ & $200.4 \pm 6.7$ & $289.7 \pm 14.1^{* * \star}$ \\
Fat pad weight $(\%)$ & $4.1 \pm 0.3$ & $8.9 \pm 0.8^{\star \star \star}$ \\
Heart weight $(\%)$ & $0.30 \pm 0.07$ & $0.28 \pm 0.07$ \\
Insulin $(\mathrm{mU} / \mathrm{mL})$ & $4.08 \pm 0.30$ & $4.54 \pm 0.84$ \\
Glucose $(\mathrm{mg} / \mathrm{dL})$ & $127.51 \pm 7.44$ & $128.5 \pm 3.2$ \\
Triglycerides $(\mathrm{mg} / \mathrm{dL})$ & $112.3 \pm 13.7$ & $117.7 \pm 14.5$ \\
Fatty acids $(\mathrm{mmol} / \mathrm{L})$ & $0.64 \pm 0.05$ & $0.60 \pm 0.09$ \\
Glycerol $(\mathrm{mmol} / \mathrm{L})$ & $173.6 \pm 8.9$ & $191.4 \pm 10.3$ \\
\hline
\end{tabular}

II), however, neither plasma triglycerides, fatty acids or glycerol were changed by cafeteria diet. These models of dietary obesity are very useful in the characterization of the molecular mechanisms implicated in human obesity, since most human obesity is thought to occur in response to high fat diets (2).

Our interest was to explore the influence of a high fat diet on heart gene expression, specifically HFABP and UCP2. Interestingly, we found a significant reduction of about $75 \%$ in HFABP mRNA levels of obese rats compared to control (Fig. 1). It has been reported that HFABP levels parallel lipid oxidation in a number of situations. HFABP deficient mice exhibit a severe defect of peripheral long-chain fatty acids utilization, while HFABP expression levels are increased in response to fasting, corresponding to a higher oxidation status (13). In our model, the downregulation of HFABP expression levels may account for lipid accumulation.

In regard to UCP2, we also obtained that obese rats had lower cardiac muscle UCP2 expression levels (-65\%) compared to control animals (Fig. 1). The UCP2 function is not totally understood and a variety of factors have been showed to modify UCP2 levels in a tissue-dependent
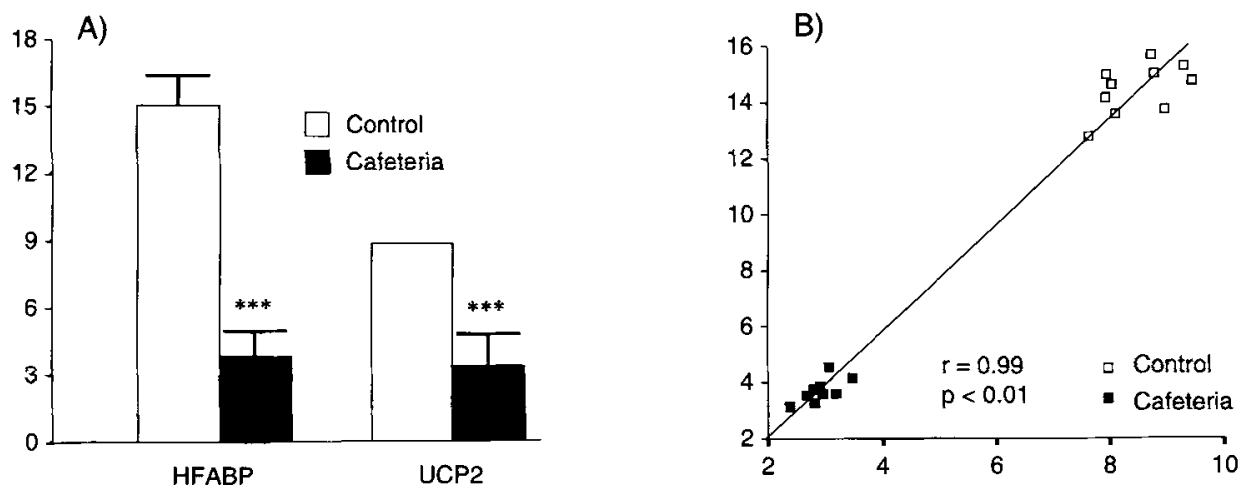

Fig.1. Effect of the cafeteria diet on beart gene expression of HFABP and UCP2 (A). Correlation between $H F A B P$ and UCP2 $m R N A$ levels $(B)$.

Gene expression is referred as $\beta$-actin levels. ***p $<0.001$. 
way. UCP2 is upregulated by leptin in adipose tissue and pancreatic islets and, thyroxin administration increased UCP2 in cardiac and skeletal muscle $(8,16)$. Boss et al. showed that cold exposure increased UCP2 mRNA in heart and BAT, while fasting had no effect on UCP2 mRNA expression (5). In response to fasting, UCP2 is also increased in skeletal but not in cardiac muscle (5). In neonatal cardiomyocytes, fatty acids promoted UCP2 expression, although UCP2 mRNA levels in the adult heart were less sensitive to changes in cardiac fatty acid handling (14). In skeletal muscle, UCP2 expression was downregulated in diet-induced obese rats (3).

In our study we showed that the heart expression levels of HFABP and UCP were highly correlated in obese and control animals, suggesting that their expressions may be controlled by the same mechanism. Similarly, MARGareTo et al. (9) found also a statistically significant correlation between FABP (ap2), UCP3 and PPARy mRNA levels in white adipose tissue from control and obese animals.

Since the nuclear receptor peroxisome proliferator-activated recpetor gamma (PPARy) controls the expression of several fat-related genes, it may also regulate the expression of HFABP and UCP2 in heart.

We conclude that dietary obesity in rats is accompanied by a down-regulation of cardiac HFABP and UCP2 gene expression. Additional experiments will be necessary to further characterize the effect of high fat diets on heart function.

\section{Acknowledgments}

This work was supported by the University of Navarra (LE-Obesidad) and the Navarra Goverment. The expert technical assistance of V. Ciaurriz and A. Lorente is acknowledged. J. M. was a student of the Master on Drugs Design at the University of Navarra.
A. MARTI, J. VAQUERIZO, M. A. ZULET, M. J. MORENO-ALIAGA y J. A. MARTÍNEZ Expresión reducida de HFABP y UCP2 en músculo cardíaco de ratas obesas (dieta de cafetería). J. Physiol. Biochem., 58 (2), 69-74, 2002.

La proteína de unión de ácidos grasos (HFABP) y la proteína desacoplante (UCP2) presentes de forma abundante en el músculo cardíaco podrían tener un papel importante en el balance energético y/o en la oxidación de las grasas. Con el objetivo de estudiar si la obesidad altera la expresión de genes en el corazón, se evalúan los niveles de expresión de la UCP2 y de HFABP en músculo cardíaco de rata mediante un modelo de obesidad inducida por dieta de cafetería. Los animales se alimentan con la dieta de cafetería durante 65 días, mostrando un aumento significativo en la ganancia de peso y en la masa grasa total en relación con el grupo control. Los niveles de expresión de la proteína de unión de ácidos grasos específica y de la proteína desacoplante 2 disminuyen significativamente $(75 \%$ y $65 \%$ respectivamente) en el músculo cardíaco de animales obesos, lo que podría estar relacionado con una menor utilización de grasas. Además, los niveles de expresión de ambos genes se correlacionan significativamente en animales obesos y control, lo que sugiere la existencia de un idéntico mecanismo nuclear para el control de la expresión.

En resumen, la alimentación rica en grasa parece disminuir los niveles de expresión de la HFABP y de la UCP2 en el músculo cardíaco de rata.

Key words: Dieta de cafetería, UCP2, HFABP, Corazón.

\section{References}

1. Abate, N. (1999): Am. J. Med., 107, 12-13.

2. Astrup, A., Lundsgaard, C. and Stock, M. J. (1998): Int. J. Obes., 22, 375-376. 
3. Berraondo, B., Marti, A., Duncan, J. S., Trayhurn, P. and Martinez, J. A. (2000): Int. J. Obes. Relat. Metab. Disord., 24, 156-163.

4. Binas, B., Danneberg, H., McWhir. J., Mullins, L. and Clark, A. J. (1999): FASEB J., 13, 805-812.

5. Boss, O., Samec, S., Dulloo, A., Seydoux, J., Muzzin, P. and Giacobini, J. P. (1997): FEBS Lett., 412, 111-114.

6. Chomczynski, P. and Sacchi, N. (1987): Anal. Biochem., 162, 156-159.

7. Corbalán, M. S., Margareto, J., Martínez, J. A. and Marti, A. (1999): J. Physiol. Biochem., 55, 67-72.

8. Lanni, A., De Felice, M., Labardi, A., Moreno, M., Fleury, C., Ricquier, D. and Goglia, F. (1997): FEBS Lett., 418, 171-174.

9. Margareto, J., Gómez-Ambrosi, J., Marti, A. and Martínez, J. A. (2001): Biochem. Biophys. Res. Commun., 283, 6-11.

10. Margareto, J., Marti, A. and Martinez, J. A. (2001): J. Nutr. Biocbem. 12, 130-137.

11. Memon, R. A., Bass, N. M., Moser, A. H., Fuller, J., Appel, R., Grunfeld, C. and Feingold,
K. R. (1999): Biochim. Biophys. Acta, 1440, 118126.

12. Petzold, T., Feindt, P., Sunderdiek, U., Boeken, U., Fischer, Y. and Gams, E. (2001): Eur. J. Cardiothorac. Surg., 19, 859-864.

13. Schaap, F. G., Binas, B., Dannenberg, H., Van der Vusse, G. J. and Glatz, J. F. (1999): Circ. Res., 85, 329-337.

14. Teshima, Y., Saikawa, T., Yonemochi, H., Hidaka, S., Yoshimatsu, H. and Sakata, T. (1999): Biochim. Biophys. Acta, 1448, 409-415.

15. Van Breda, E., Keizer, H. A., Vork, M. M., Surtel, D. A. M., de Jong, Y. F., Vander Vusse, G. S. and Glatz, J. F. C. (1992): Pflügers Arch., 421, 274-279.

16. Van der Lee, K. A., Willemsen, P. H., Van der Vusse, G. J. and Van Bilsen, M. (2000): FASEB J., 14, 495-502.

17. Zhou, Y. T., Grayburn, P., Karim, A., Shimabukuro, M., Higa, M., Baetens, D., Orci, L. and Unger, R. H. (2000): Proc. Natl. Acad. Sci. USA, 97, 1784-1789. 